\title{
1 Optimization of virtual water flow via grain trade within China
}

2 Zongzhi Wang ${ }^{\mathrm{a}, ~ *}$, Lingling Zhang ${ }^{\mathrm{b},}$, , Qing Zhang ${ }^{\mathrm{b}}$, Yi-Ming Wei ${ }^{\mathrm{c},}{ }^{*}$, Jin-Wei Wang ${ }^{\mathrm{c}}$, Xueli Ding ${ }^{\mathrm{b}}$,

3 Zhifu $\mathrm{Mi}^{\mathrm{d}}$,*

4 a State Key Laboratory of Hydrology-Water Resources and Hydraulic Engineering, Nanjing Hydraulic Research

5 Institute, Nanjing 210029, China

$6 \quad$ b School of Public Administration, Hohai University, Nanjing, 210098, China

$7 \quad$ c Center for Energy and Environmental Policy Research, Beijing Institute of Technology, Beijing 100081, China

${ }^{d}$ The Bartlett School of Construction and Project Management, University College London, London WC1E 7HB,

$9 \quad U K$

\footnotetext{
${ }^{*}$ Corresponding author. Tel.: +86 25 85828506; Fax: +86 2585828555

Email addresses: wangzz77@163.com (Z.Z.Wang), lzhang007@163.com (L.L.Zhang), wei@bit.edu.cn (Y.-M. Wei), z.mi@ucl.ac.uk (Z.F. Mi)
}

Abstract: The irrational virtual water flow caused by grain trade makes water use efficiency low and further threatens grain security in China. However, optimizing the grain virtual water trade flow from the perspective of the economic value of water resources has rarely been carried out in current research. This paper proposes a linear optimization model considering opportunity cost to fill this gap. The current situation of grain virtual water trade is analyzed and we find an irrational trade mode which quantity and direction of grain virtual water trade in some provinces are not consistent with actual demand. Then, opportunity cost is added to the linear optimization model to adjust grain virtual water trade which shows several advantages compared to general linear optimization model. Results show that huge virtual flow is generated, up to 1179.24 billion cubic meters of water. And the economic value generated by grain virtual water trade can not only cover the transportation cost but can also eventually generate economic benefits of 7410 billion yuan. Finally, the relevant conclusions 
and implications of adjusting China's grain virtual water trade are obtained.

Keywords: Inter-provincial grain trade; virtual water flow; linear programming; opportunity cost;

\section{Introduction}

Problems related to water is considered the grimmest challenges in China due to the low availability of per capita volume. China's average water availability is $2300 \mathrm{~m}^{3} /$ year, only accounting for $1 / 3$ of the average of world. What's worse is that North China supports more than half of the total population with merely $20 \%$ of the total water resources and approximately $1 / 8$ of the national level in terms of per capita water availability. Flourishing trade activities on both domestic and international levels are expected to contribute to the ever increasing levels of water consumption (Guan et al., 2007). As a production link with high water consumption and low economic returns, grain production plays an important role in water utilization, economic development and social stability. The virtual water strategy constructs a bridge between water resource management and food security by changing the traditional thinking of relying on engineering and technological means to solve the problem of water shortage. Virtual water has been recognized as a potentially useful concept for redistributing water from water-rich to water-poor regions (Feng et al., 2012), that is, the indirect allocation of water resources by economic ties.

However, from the perspective of virtual water, China's grain trade shows the pattern of "the north water moves to the south" (Hoekstra and Hung, 2002). The virtual water flow from north to south from 2004 to 2013 was approximately 42.6 billion $\mathrm{m}^{3} /$ year and the irrigation water was accounts for approximately $10 \%$ of the water consumption for crop production in the North (Jiang et al., 2017). For China, this transfer, along with scarce water resources and uneven distribution, is a serious threat to the sustainable development of agriculture. This pattern is the result of comprehensive factors, such 
as water and soil resource matching, economic development, population size and so on (Jiang et al., 2015). Therefore, remolding the water trade relationship is an important supplementary tool in solving water shortage (Zhang and Anadon, 2014).

And trade is a means of transferring water resources between regions. The virtual water trade is a powerful accounting tool mapping the linkages between trade activities and anthropogenic water use (Chen and $\mathrm{Li}, 2015)$. Thus, evaluating the virtual water flow via China's inter-provincial grain trade has significant policy implications. However, to the best knowledge of the authors, there are few studies on optimizing the grain virtual water trade flow from the perspective of the economic value of water resources. Many researches have advocated virtual water as a strategy due to the comparative advantage of water resources, to be specific, that is a water-scarce country can aim at importing waterintensive products and exporting water-extensive products (Hoekstra and Hung, 2005). Therefore, existing researches only emphasize the endowment conditions of the water resources but ignore the other factors when applied virtual water strategy. And the comparative advantages of virtual water strategy are only gained from the perspective of water resources endowment resulting that the choice of virtual water trade in this situation lacks overall consideration.

The water embodied in virtual water trade can also be used in other purposes such as economic development and environment requirement. Thus, it is necessary to take the opportunity cost factor into consideration in in weighing the pros and cons of the virtual water trade. The so-called opportunity cost is, when a decision is made, the loss of the potential benefit of giving up another scheme is caused by the choice of a better scheme. Since this potential benefit is a possible choice, the decision-makers cannot only consider the resources of sacrifice when measuring the benefits of a particular scheme (the actual cost) but they also compare the loss of the benefit (opportunity cost) 
resulting from the other suboptimal schemes. Therefore, the opportunity cost is the related cost of decision making and is of great significance to decision-making. Finally, we choose the economic value of water resources as the opportunity cost. To this end, this paper, based on the current situation of grain production and consumption of virtual water, quantifies and adjusts the grain virtual water trade structure from the perspective of the economic value of water resources to fill gap in this area.

This paper attempts to address three issues:

(1) What is the current situation of grain virtual water trade?

(2) How can grain virtual water trade be optimized?

(3) What are the advantages of the optimized method of grain virtual water trade other than the general optimization?

\section{Literature review}

\subsection{Virtual water trade}

Professor Allan $(1993 ; 1994)$ first proposed the concept of virtual water and defined the amount of water consumed for production goods and services as "virtual water". Hoekstra and Hung (2005) put forward the concept of the "water footprint" based on the virtual water used to measure and calculate the water consumption of a certain area after the virtual water flow.

81

Many virtual water trade studies have been conducted on multiple levels with many meaningful results. At the global level, the virtual water flows related to international rice trade $31 \mathrm{~km}^{3} /$ year (Chapagain and Hoekstra, 2011). Global virtual water trade was estimated and $450 \mathrm{~km}^{3} / \mathrm{year}$ is virtually saved by global trade resulting from the comparative advantage of water use efficiency in import and output countries (Chapagain and Hoekstra, 2003). Given the importance of non-food 
product in global trade, another study was done and results show that $57 \%$ of the international virtual water flows is embodied in non-food trade (Chen and Chen, 2013). At national level, El-Sadek (2010) found that Egypt's net virtual water import as a percentage of water resources has mounted to be $23.55 \%$ and discussed the applicability of virtual water concept in the national water resources strategy of Egypt. Abu-Sharar et al. (2012) analyzed the optimization role of virtual water in water resources management in the Jordanian region and noted that continued importation of food crops will become an effective way to balance food production and save water resources. Allan et al. (2003) calculated the import and export volumes of virtual water in recent years in some countries in the Middle East and North Africa and noted that virtual water trade played an important role in guaranteeing food security. Ma et al. (2006) quantified the volumes of virtual water flows between regions in China and the results shown that the export volume of virtual water from north China to south China was $52 \mathrm{Gm}^{3} /$ year. At the provincial and basin level, Zhang et al. (2011) found that Beijing import 51\% of virtual water from other provinces. Feng et al. (2012) assessed the regional virtual water flows between the Yellow River Basin and the rest of China, and results shown that all three reaches of that are net virtual water exporter.

\subsection{Optimization of virtual water trade}

Research focused on virtual water trade pattern in China and the characteristics of virtual water trade shown from north to south and from arid regions to wet regions (Dalin et al., 2014 ). Ansink (2010) explained the phenomenon and claimed the arable land has played more decisive role in grain production than water. The paradox that arid regions transfer virtual water to wet regions is contributing to more unsustainable and uneven economic and environmental development (Chen et al., 2017). Based on previous studies, some literatures had put forward policy recommendations such 
as optimizing trade structures (Zhang et al., 2017).Virtual water provides an innovative application of virtual water trade in the traditional allocation of physical water resources in water scarce regions (Ye et al., 2018). Cheng (2003) introduced the concept of virtual water to China and noted that it is of great significance to optimize the trade structure of water-intensive agricultural products. Some unexpected challenges occurs to the governments when they wishing to implement a virtual water strategy aiming to encourage farmers to select low-valued, water-intensive crops rather than highervalued, tradable crops (Wichelns D, 2001).

In the study of inter-regional grain virtual water trade in China, Zou et al. (2010) explored the current situation of domestic grain virtual water balance and put forward the ideal layout mode of China's grain production under the background of virtual water. The direction of regional grain production adjustment is given (Zou et al., 2010). Wang et al. (2014) studied the impact of interregional food virtual water flow on the regional economy and water resources in China and noted that improving the efficiency of agricultural water use, implementing virtual water compensation and optimizing crop planting structure are the key measures to solve the negative effects of regional virtual water flow. Virtual water trade's rational foothold should be the coordination of economic development goals and water resource issues. Therefore, virtual water trade has both water-saving effects and economic values (Xu et al., 2010). Hoekstra and Hung (2002) argued that not only pricing and technology can be means to increase local water use efficiency and reallocating water, but also virtual water trade between nations can be an instrument to increase water use efficiency.

$$
\text { Linear programming is the most important method of system optimization in operational research, }
$$
and it is an applied mathematical method for the rational utilization and allocation of resources. Its basic idea is to meet certain constraints and make the target reach the optimal. The wide application 
of linear programming, in addition to its own practical characteristics, is still simple in its structure and easy to master. This method has been applied by researchers in the field of virtual water trade, such as Dalin et al. (2015), who estimated China's future food trade patterns and water transfers and measured the influences of targeted irrigated land reductions on water consumption and food selfsufficiency. Li (2018) used the interval linear multi-objective programming (ILMP) model for irrigation water allocation through considering conflicting objectives and uncertainties and indicated that the ILMP model provided effective linkages between revenue/output promotion and water saving. Domestic scholars (Dong, 2016) use the linear programming method to study the Xinjiang virtual water trade structure optimization by adjusting the sector net outflow/net export trade on the premise of ensuring the economic, environmental and social benefits. However, at present, the research on the quantitative adjustment of the grain virtual water trade pattern from the point of view of its economic value has not been carried out.

\section{Methodology}

\subsection{Research framework}

Based on the calculation of grain production and consumption in various provinces and municipalities, we can achieve the goal of virtual water balance by purchasing grain products from other regions to meet the needs of different regions to alleviate the pressure on local water resources and promote the efficient utilization of water resources.

The optimization model is improved with an additional consideration for opportunity cost to evaluate the grain virtual water trade. The objective function of the improved model is the minimization of the total cost (the sum of the transportation cost and the opportunity cost). In this way, we should adjust the current trade pattern of the inter-provincial grain virtual water and 
encourage the virtual flow of grain to the industry with higher efficiency to promote the coordinated development of China's regional economy. Fig. 1 illustrates the research framework in this study.
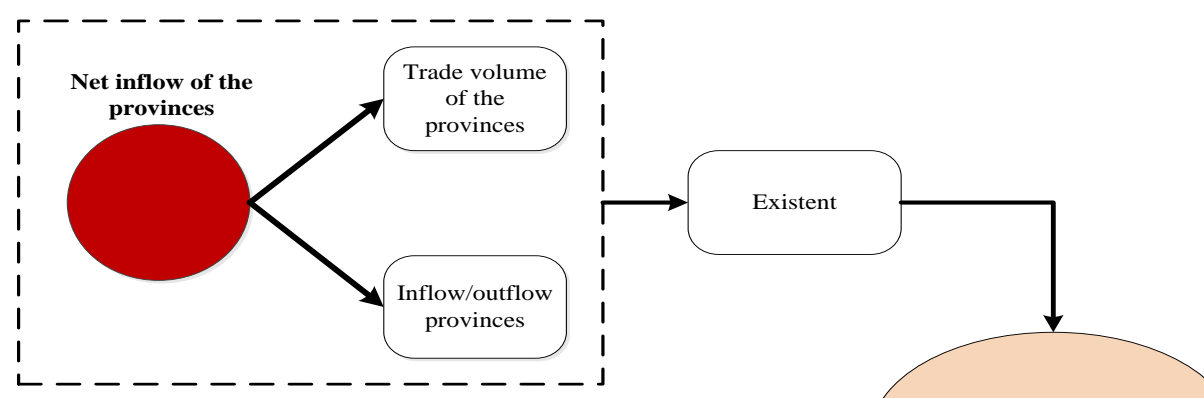

Comparison of the pattern with and without consideration of opportunity cost

The irrational interprovincial trade pattern
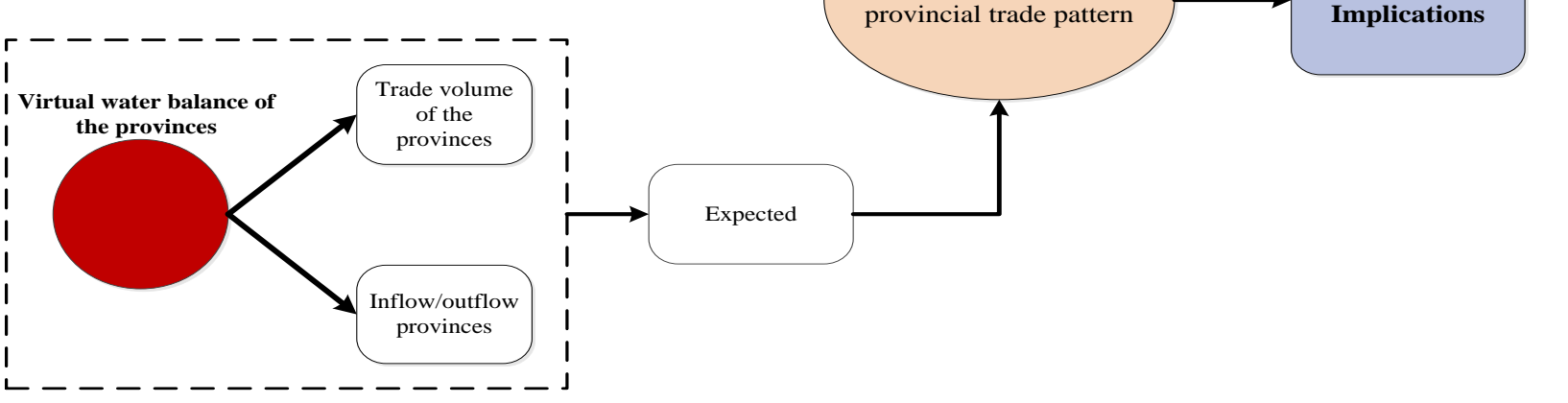

Fig. 1. Research framework for optimizing the flow pattern of inter-provincial grain virtual water trade

\subsection{Estimation of grain production, consumption and its balance with virtual water}

In this article, grain refers to grain, bean, potato and other grains, which is the same as in China's statistical yearbook. The grain production and the consumption of virtual water volume were calculated combined with various regions of China's virtual water contents. The formulas are as follows:

$P V W_{n}=P_{n} \times V W_{n}$
$C V W_{n}=C_{n} \times V W_{n}$
$B V W_{n}=P V W_{n}-C V W_{n}$

where $P V W_{n}$ is the virtual water quantity of grain production in $n$ province, $C V W_{n}$ is the virtual water quantity of grain consumption in $n$ province, $\mathrm{P}_{\mathrm{n}}$ is the grain production in $n$ province, $C_{n}$ is the grain 
consumption in $n$ province, $V W_{n}$ is the virtual water content of grain in province $n, B V W_{n}$ is the balance volume of grain virtual water in province $n$ (If the result is negative, the area needs to import grain virtual water from other regions. Conversely, the output of virtual water is needed. Therefore, the 31 provinces are divided into input and output areas).

\subsection{Trade volume of inter-regional grain virtual water}

Because more than $80 \%$ of the agricultural water is used for grain production, this paper adopts the proportion of input and output between the agricultural departments in the provinces from the 2012 input-output table to obtain the proportion of the related components of the grain trade volume. The relevant calculation in this study is only for the domestic market of virtual water trade in grain, so we do not need to consider the import and export trade data. The calculation only needs to intercept the intermediate input ratio and bring it along for the virtual water trade in grain. In this way, we can get the volume of the production of grain virtual water for each province separately as well as the amount of water transferred into the provinces. The calculation is expressed as equations (4) and (5):

$$
P V W_{n}=\alpha P O C_{i}+\beta O F_{n}
$$

in which $P O C_{i}$ is the production of grain virtual water in $i$ province used for its own consumption, $O F_{n}$ is the amount of outflow in province $n, I F_{n}$ is the amount of inflow in province $n, \alpha, \beta, \varphi$ and $\gamma$ are the corresponding constituent ratios, and the rest of the symbolic meaning is the same as above.

\subsection{An optimization model based on a cost benefit analysis}

Based on China's higher grain self-sufficiency rate and the need for a simplified model simulation, the regional grain virtual water trade model does not consider the international trade of grain. Without considering the international market, the domestic grain transportation is an unbalanced 
transportation problem whose output is larger than the demand.

On the basis of the relative stability of the food demand and supply in various regions, the model lays emphasis on the virtual water embedded in the grain. Therefore, we build a linear optimization model to adjust inter-provincial grain virtual water trade taking cost opportunity into consideration.

First, the opportunity cost refers to the value of water consumption in the industrial sector. According to the explanation of the opportunity cost (the maximum net income that may be obtained by making a choice but giving up another), we finally determine it by comparing the added value per ten thousand yuan of water used by the agricultural and industrial. In all regions, the amount of water needed for agriculture to produce ten thousand yuan added value is much larger than that of industry. The former is several times that of the latter. The difference in resource utilization efficiency indirectly confirms the real economic significance of mobilizing social resources and transferring water resources to non-agricultural use in the new theory of virtual water.

Second, the optimization model is constructed based on two assumptions: first, the market is perfectly competitive and fully circular, leading to the consideration of grain as a homogenous product. Second, Grain-deficit provinces primarily receive from grain-surplus provinces, which has been adopted by this study (Zhuo et al., 2016). Compared with grain production and consumption, 31 provinces can be divided into grain-deficit provinces and grain-surplus provinces. Therefore, grain trade virtual water outflow area and inflow area can also be determined.

Third, the model is an improvement to the general linear programming model, which means that the total cost (transportation cost and opportunity cost) is minimized as the objective to adjust the inter-regional trade pattern of grain virtual water. The profitability of grain trade is affected by the basic position of agriculture in the national strategy, and logistics are directly related to grain trade. 

Therefore, it can be understood that grain circulation trade seeks the minimum transportation cost and

211 obtains greater economic benefits. In the same way, virtual water trade with grain as the carrier also 212 complied with the characteristics of economic benefit. Furthermore, the opportunity cost (that is water 213 for industrial purpose) is well considered to achieve a better understanding of virtual water trade's 214 advantages.

215 The linear optimization model to adjust the inter-regional trade pattern of grain virtual water is as 216 follows.

217 Objective function:

$$
\min T=\sum_{i=1}^{M} \sum_{j=1}^{M-n} x_{i j} b_{i j}
$$

219 Constraints:

$$
\begin{gathered}
\sum_{j=1}^{M-n} x_{i j}=M I Q_{i} \\
\sum_{i=1}^{n} x_{i j} \leq M O Q_{j}
\end{gathered}
$$

$$
c_{i j}=F \cdot d_{i j}
$$

$$
b_{i j}=c_{i j}+\left(\frac{1}{p_{w j}}-\frac{1}{p_{w i}}\right)
$$

$$
M I Q_{i}, M O Q_{j}, x_{i j}, c_{i j} \geq 0
$$

226 In the formula, $T$ is the total cost of inter-provincial grain virtual water trade, that is, transportation cost and opportunity cost, and the total cost minimization is the objective function. $x_{i j}$ is the volume 
of grain virtual water from the province $j$ to the province $i, i$ is the province that flows into the grain virtual water, and $j$ is the province that outflows from the grain virtual water. $n$ is the total number of provinces flowing into the grain virtual water, while $M-n$ is the total number of provinces flowing out of the grain virtual water. $c_{i j}$ is the cost of virtual water transport in unit grain from $j$ to $i, F$ is the cost of unit grain virtual water transportation, $d_{i j}$ is the transportation distance from $j$ to $i, M I Q_{i}$ is the deficiency of the grain virtual water of province $i, M O Q_{j}$ is the surplus of grain virtual water of province $j, p w_{j}$ and $p w_{i}$ are the water use of industrial added value per ten thousand yuan in province $i$ and province $j, 1 / p w_{j}$ and $1 / p w_{i}$ are ten thousand yuan industrial added value for each unit of grain virtual water from $j$ to $i$ and from $i$ to $j$, and $b_{i j}$ is the cost of grain virtual water trade from $j$ to $i$. The formula (7) is the inflow constraint from the other provinces to the province in question, which is equal to an insufficient amount for that province to meet the grain demand. The formula (8) indicates the outflow constraint from the province in question to other provinces, which is less than or equal to the surplus of that province, ensuring grain supply in the grain surplus provinces within the scope of their own grain supply capacity. The formula (9) is the condition of trade circulation, that is, the trade happens only when virtual water flow from low water productivity to high water productivity. The formula (10) and (11) are transportation cost and total cost respectively. The formula (12) expresses that all these variables are positive.

\subsection{Data}

Taking 2014 as a time point, the grain data (the grain mainly consists of rice, wheat, maize, soybeans and potatoes, of which the statistical caliber is consistent with the statistical yearbook) of China's 31 provincial administrative regions (excluding Hong Kong, Macao and Taiwan) are selected to optimize and analyze the inter-provincial grain virtual water trade pattern in China.

\section{(1) Grain output and consumption in all provinces}

The raw data for grain output and consumption were derived from the "China Statistical Yearbook" 
(2015), the "China Food Industry Yearbook" (2015), the "China Rural Statistical Yearbook" (2015) and the statistical yearbooks of the provinces and cities. Based on the existing research, this paper divides the consumption of grain into five categories: ration consumption, feed consumption, industrial consumption, seed consumption and grain loss, according to the use of grain. According to the research of scholar Yang's literature (2009), the grain consumption is calculated according to the general index and a certain proportion of conversion. The ration consumption includes household and outside consumption of the family. Household food consumption is calculated by per capita grain consumption multiplied by the resident population, where the additional grain consumption of the family comprises $16 \%$ of the household food consumption. Feed consumption is based on the international general feed conversion rate, combined with the habit of feeding livestock and fish in China, in line with the following ratio conversions: pork 1:3.5, beef and mutton 1:1.7, poultry 1:1.7, eggs 1:2.2, fish 1:0.9 to calculate the feed food for different kinds of livestock, poultry, and fish. The industrial consumption, alcohol, liquor, beer, monosodium glutamate and other purposes in accordance with the conversion ratio is estimated: alcohol 1:3, white wine 1:2.3, beer 1:0.172, monosodium glutamate 1:2.4, and other industrial uses of grain, which are in accordance with $25 \%$ of the above. Seed consumption is calculated by various crop planting areas multiplied by seed consumption per unit area, and the seed consumption per unit is as follows: rice is $75 \mathrm{~kg} / \mathrm{ha}$, corn is $75 \mathrm{~kg} / \mathrm{ha}$, soybean is $75 \mathrm{~kg} / \mathrm{ha}$, and other grain uses are $225 \mathrm{~kg} / \mathrm{ha}$. Grain loss includes inventory loss, transportation loss and processing loss, and inventory loss is calculated by $2 \%$ grain production, transport and processing loss are calculated by $4 \%$ and $5 \%$, respectively, of the sum of ration consumption, feed consumption, and industrial consumption. Because the inventory is ultimately converted to consumption, it does not consider the factors of inventory. According to the above methods, the consumption of grain in China is obtained. 
The trade volume between provinces was derived from the 2012 input-output table compiled by the National Bureau of Statistics (the input-output table was compiled for five years as a cycle, and the current version is the latest one).

The input-output table is divided into six departments, and we selected the agricultural sector of the inter-provincial input-output ratio to calculate the grain trade volume relative proportions; through the virtual water content of grain production in each province, the quantity of local virtual water consumption and the amount of inter-provincial virtual water mobilization are calculated.

\section{(3) The cost data of grain transportation}

The circulation of China's inter-provincial grain trade is mainly by railway, referring to Ben's study (2016). The distance of grain transportation is based on the odometer of the main railway stations nationwide. Some provinces take the shortest mileage of the provincial capital cities in the national railway mileage query as supplementary. The average cost of national grain transport per mile is obtained by railway freight inquiry. Then, combined with the virtual water content of various provinces and cities of China, the transportation cost of the inter-provincial virtual water trade unit is calculated. 
The water used for agricultural added value per ten thousand yuan is obtained by the ratio of 300 agricultural water to agricultural added value. We use the agricultural added value from the "Chinese Statistical Yearbook" (2015) and the agricultural water consumption of all the provinces from "China's Environmental Yearbook" (2015) as the original data. The water used for industrial added value per ten thousand yuan are taken directly from the water resources bulletin of various regions in 2014.

\section{Results and discussions}

\subsection{Current situation of inter-regional grain virtual water trade}

of grain production and the virtual water of grain consumption in each province. The positive value represents the virtual inflow of water, and the negative value represents the virtual outflow of water.

310 Through comparing each province's actual net inflow of grain virtual water with their balance volume of grain virtual water, we found a certain degree of difference in both trade volume and trade direction, as seen in Fig. 2. 


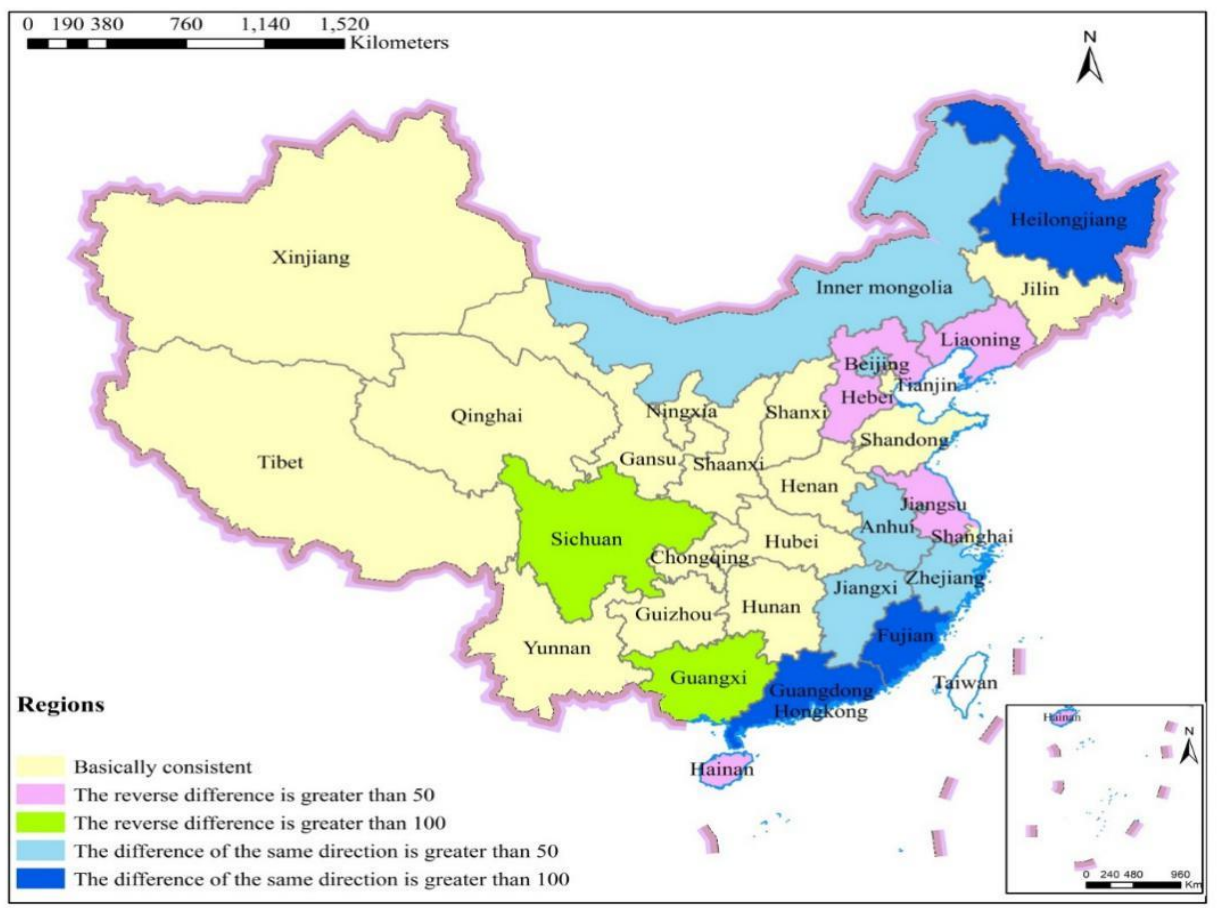

Fig. 2 Differential diagram of provincial grain virtual water trade net inflow volume and balance volume

Notes: There are five categories of the legend. The "basically consistent" category indicates that it can basically achieve the balance of the grain virtual water from the two aspects of flow volume and flow direction. "The reverse difference is greater than 50" and "the reverse difference is greater than 100" categories both represent the direction of the grain virtual water trade is opposite to that of the balance volume. In addition, the difference of net inflow volume and balance volume is greater than 50 billion cubic meters and 100 billion cubic meters, respectively. "The difference of the same direction is greater than 50" and "the difference of the same direction is greater than 100" categories indicate that the direction of the grain virtual water trade in the province is the same as the direction of the balance, but the quantity difference is greater than 50 and 100 billion cubic meters, respectively.

Although, in most provinces, the direction of grain virtual water trade is the same as the direction of their grain balance volume in 2014, some provinces still have differences, namely, the grain virtual water surplus area is transferred into the virtual water while the deficit area is transferred out of the virtual water.

The grain virtual water trade in 17 provinces is basically consistent with the local balance of grain virtual water, and there are obvious differences in the 14 provinces. There are reverse flows in Hebei, Liaoning, Jiangsu, Guangxi, Hainan and Sichuan. This means that they have not exported to other 
places even though they have the ability to output grain virtual water and, instead, they have transferred from other places to the grain virtual water. The other case is that they did not transfer from other provinces, even though they needed to input food virtual water. Instead, they exported a certain amount of grain virtual water to other provinces.

From the amount of flow, there is much reverse flow in Sichuan and Guangxi, and their differences are of the degree of more than 100 billion cubic meters. For the remaining 4 provinces, the reverse flow is smaller, a difference of 50-100 billion cubic meters. There are 8 provinces that have positive flow, but there was a significant difference between the volumes of flow; for example, in Heilongjiang, Zhejiang, and Guangdong, the difference is more than 10 billion cubic meters. Five provinces with positive flow have a small difference of 50-100 billion cubic meters.

From a regional perspective, the total virtual water net inflows are -245.28 billion cubic meters, while the south is 74.64 billion cubic meters. This shows the phenomenon that the virtual water flow from the north to the south, which aggravates the unbalanced allocation of regional resources to a certain extent. Besides, this trade pattern is not conducive to the balance of grain supply and demand for each province. For the output sites without the virtual water capacity of output, the sustainable development of agricultural production and water resources is not guaranteed, and it will exacerbate the pressure of local water resources and threaten food production. For input sites, if we cannot efficiently utilize the virtual water resources flowing through the grain trade, we will cause indirect waste, which is not conducive to the development of the whole society and economy.

\subsection{Optimization of grain virtual water trade with opportunity cost}

Through the simulation of the model, we have solved the trade volume of China's inter-provincial grain virtual water and obtained its flow and flow direction. 


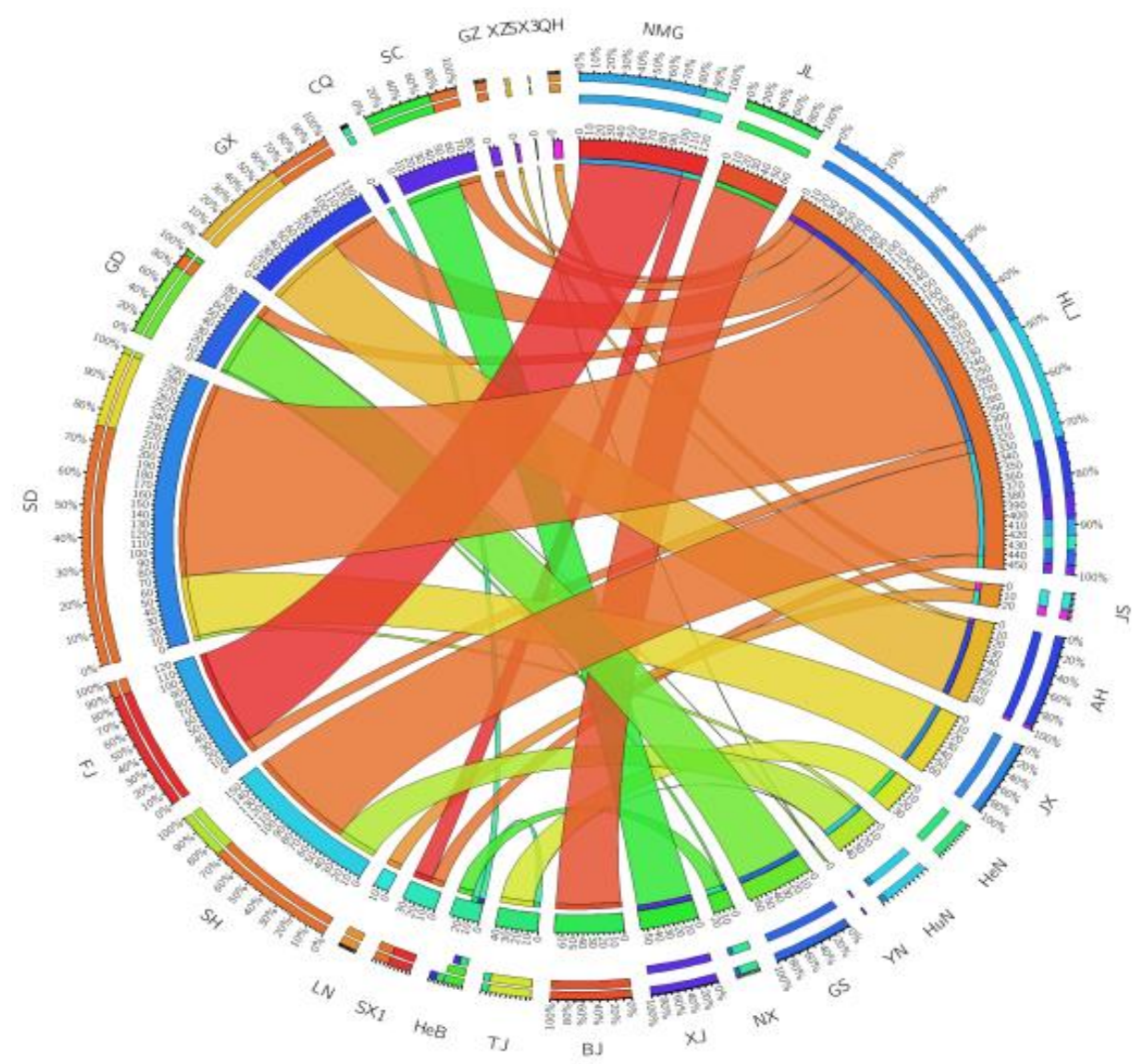

Fig. 3 An optimization simulation of China's inter-provincial virtual water trade, considering the opportunity cost in 2014

Notes: These provinces are the virtual water output areas, the specific location is from NMG (Inner Mongolia) clockwise direction to XJ (Xinjiang). And the total is 13 provinces. Those provinces are virtual water input areas, the specific location is from BJ (Beijing) clockwise direction to QH (Qinghai). And the total is 18 provinces. There are 31 provinces (municipalities, autonomous regions) in the mainland of China, namely, Beijing (BJ), Tianjin (TJ), Hebei (HeB), Shanxi (SX1), Inner Mongolia (NMG), Liaoning (LN), Jilin (JL), Heilongjiang (HLJ), Shanghai (SH), Jiangsu (JS), Zhejaing (ZJ), Anhui (AH), Fujian (FJ), Jiangxi (JX), Shandong (SD), Henan (HeN), Hubei (HuB), Hunan (HuN), Guangdong (GD), Guangxi (GX), Hainan (HaN), Congqing (CQ), Sichuan (SC), Guizhou (GZ), Yunnan (YN), Tibet (XZ), Shaanxi (SX3), Gansu (GS), Qinghai (QH), Ningxia (NX), Xinjiang (XJ). The arc connects virtual water outflow and inflow areas; the thicker the arc is, the larger the virtual water flow is. For the convenience of analysis, the points connected to both ends of the input and output are called the receiving points and the sending points, respectively.

From Fig. 3, there are 18 input areas and 13 output areas in the grain virtual water trade with total cost minimization. In the provincial grain virtual water trade, the virtual water flow is a total of 1179.24 billion cubic meters, which accounted for $4.32 \%$ of the total water resources of the country in 2014 , accounting for $30.47 \%$ of the agricultural water. It can be seen that the flow of virtual water 
resources caused by grain trade is an indisputable fact, and the impact on various areas cannot be 371 ignored.

From the number of sending and receiving points and their virtual amounts of water, there are 9 sending points in Heilongjiang Province, which is the largest in the output area. Of these, 218.11 billion cubic meters were shipped to Guangdong, which accounts for more than $50 \%$ of the total output, followed by Zhejiang (112.57 billion cubic meters) and Liaoning ( 72.46 billion cubic meters). There are 4 receiving points in Guangdong Province, which is the largest in the input area. This area mainly receives grain virtual water from Heilongjiang, Ningxia, Gansu and Yunnan provinces, approximately 218.11 billion cubic meters, 3.39 billion cubic meters, 67.68 billion cubic meters and 1 billion cubic meters, respectively. The 11 input provinces have one receiving point. Meanwhile, 3 output sites have one sending point

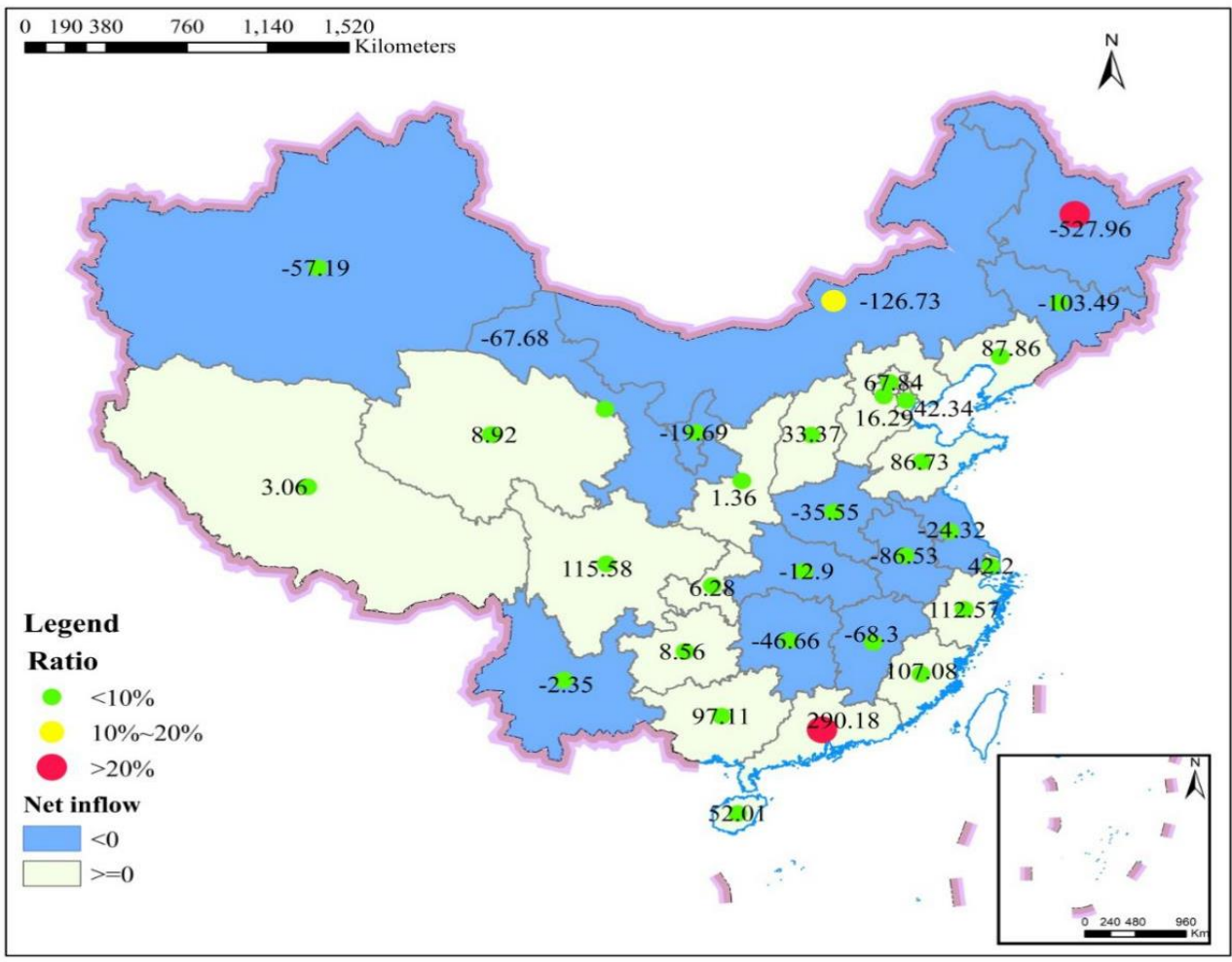


point is the virtual water net flow ratio of the provinces.

From Fig. 4, we can see that the grain virtual water net flow accounts for more than $20 \%$ of the total in only one province, namely, Heilongjiang province and Guangdong province. Only the output of virtual water in Inner Mongolia is in the ratio of $10 \%-20 \%$ to the total output. The rest of the provinces' net virtual water momentum of grain is less than $10 \%$. Combined with the specific trade volume, it can be concluded that for the output area, the first $23 \%$ provinces outflow approximately $70 \%$ of the virtual water volume, indicating that the concentration of resources is high and a small number of areas occupy an advantageous position..

\subsection{Advantages of the model}

The construction of the optimization model of grain virtual water trade has its inherent advantages. First, the grain virtual water trade pattern after optimization can not only meet the domestic regional grain consumption, but also can fully realize the inter-provincial free flow of grain. Second, it is undoubtedly a new perspective of water resources management to adjust the volume and direction of inter-regional virtual water through grain trade. Additionally, it can not only achieve the virtual water balance in the input area but also strengthen the productivity of the limited water resources in the provinces and create higher economic benefits.

Combined with the operation results of the general optimization model (linear optimization with the objective of minimizing the cost of transportation), we compared the advantages with the case that considered the opportunity cost. The specific contents are as follows: 


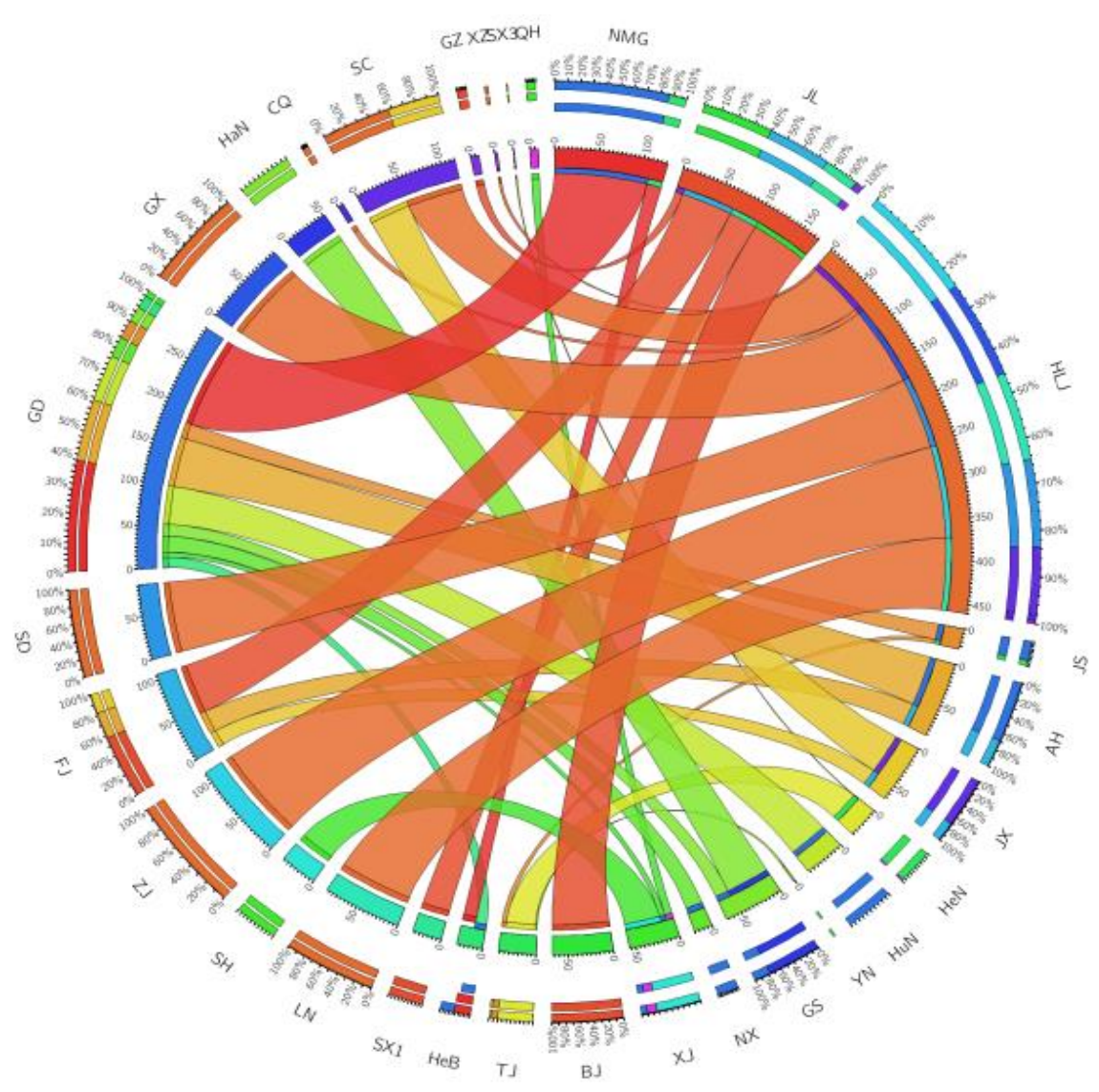

Fig. 5 An optimization simulation of the minimum transportation cost of China's inter-provincial virtual water trade in 2014

Notes: These provinces are the virtual water output areas, the specific location is from NMG (Inner Mongolia) clockwise direction to $\mathrm{XJ}$ (Xinjiang). And the total is 13 provinces. Those provinces are virtual water input areas, the specific location is from BJ (Beijing) clockwise direction to QH (Qinghai). And the total is 18 provinces. In addition, the descriptions of China's provinces is the same with Fig.3.

(1) Comparing Fig. 3 with Fig. 5, we can see that they both have 31 outlets, which indirectly indicates that the trade network of grain virtual water doesn't become more complicated. The main changes are the trade direction and the specific volume of trade. In Fig. 3, Heilongiiang still has the largest number of sending points. The number of sending points to other provinces is more than in Fig. 5, from 8 to 9. The largest number of recipients in Fig. 3 is still in Guangdong Province, but the number of receiving points has changed to 4 , which is half of what it was before. Next, the number of receiving points increased to 3, including Guangdong, Shandong and Tianjin. The point distribution in Fig. 5 is more dispersed than Fig. 3 overall. 


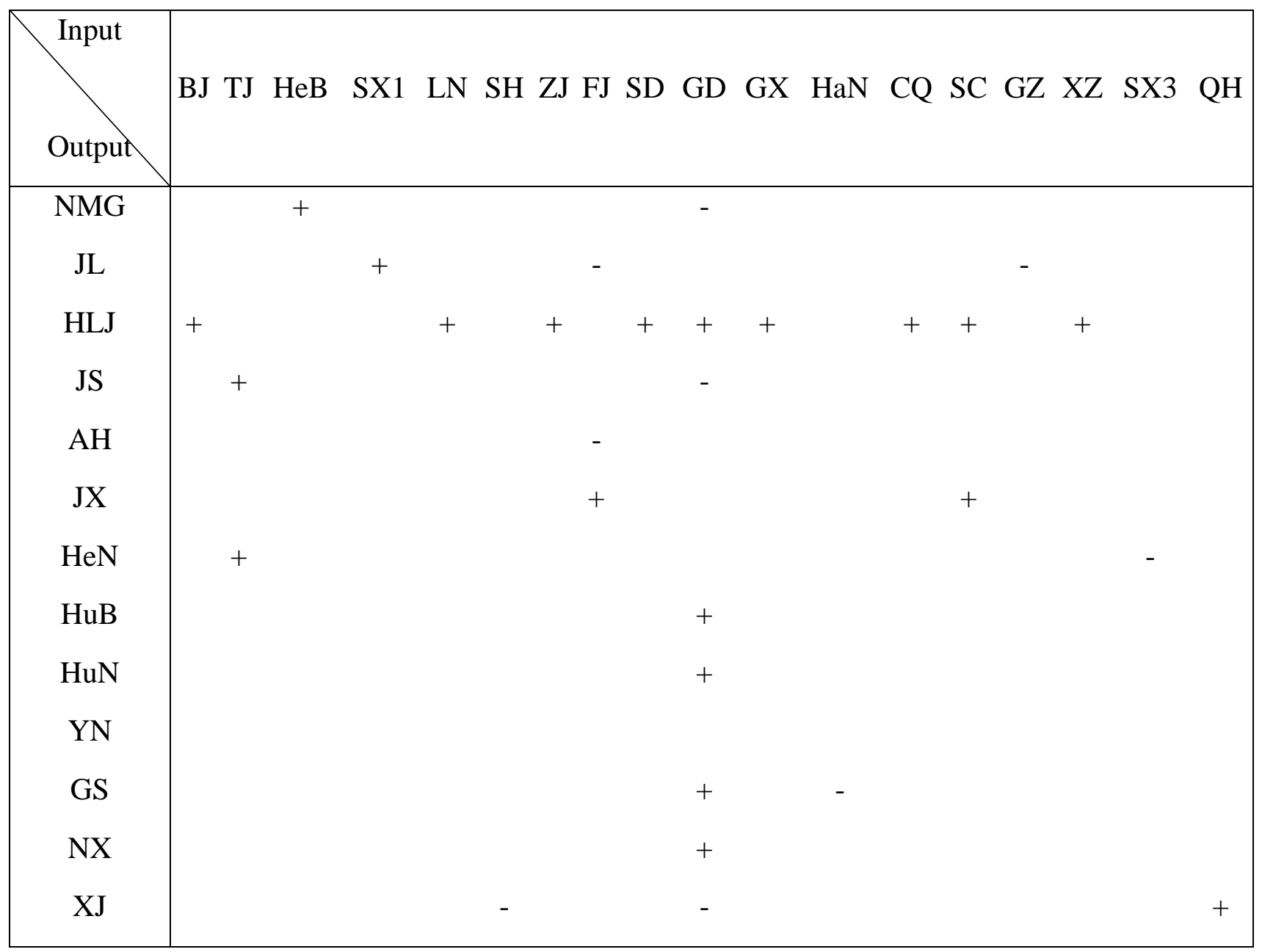

Notes: In the optimization model with the minimum transport cost as the objective function, meeting the conditions of formula (9) is a plus and otherwise is a minus.

(2) Combined with table 1, it is found that during the grain virtual water trade pattern under the minimum transportation cost optimization model, many output areas are not reasonable in choosing the direction of grain virtual water trade. The output direction of 7 provinces in 13 output areas is unreasonable, including Inner Mongolia to Guangdong, Jilin to Fujian and Guizhou, Jiangsu to Guangdong, Anhui to Fujian, Henan to Shaanxi, Gansu to Hainan, and Xinjiang to Shanghai and Guangdong. This unreasonable phenomenon is attributed to the higher opportunity cost in those output areas than in the input areas, resulting in the inefficient utilization of water resources. Therefore, the optimization of the grain virtual water trade pattern will be more conducive to the optimal 
allocation and efficient utilization of resources after considering the opportunity cost.

(3) Combining Fig. 2 with Fig. 4, from the number of receiving and sending points and their amounts of virtual water in the two optimization results, the long-tail effect of a trade optimization scheme considering the opportunity cost is more obvious than the optimization scheme that considers only the cost of transportation. The former is closer to the two-eight distribution law, which means that the result is closer to the actual situation. This result has further clarified the provinces dominated by grain virtual water trade.

(4) From the analysis of the optimization results, we concluded that the total transportation cost of the optimized trade pattern was 14.05 billion yuan, accounting for only $4.35 \%$ of the agricultural output value when considering the objective function with the minimum transportation cost. When considering the opportunity cost in trade, the economic value generated can not only cover the transportation cost but can also eventually generate economic benefits of 7410 billion yuan. These data are nearly 230 times the total output value of agriculture in 2014 . Therefore, we can see that the opportunity cost of grain virtual water trade has great significance for promoting the overall development of the national economy.

\section{Conclusions and policy implications}

Based on the current situation of grain production and consumption, this paper calculates the virtual amount of water behind its production and consumption and analyze the balance of grain virtual water trade in various regions. The following conclusions were obtained.

(1) The current situation of grain virtual water trade

Comparing the grain virtual balance volume and net inflow volume, we find that the grain virtual 
water trade is unreasonable, mainly from two aspects of flow direction and flow volume. In terms of flow direction, some virtual water surplus areas do not export virtual water but import virtual water from other places. Meanwhile, some virtual water shortage areas do not import virtual water from other places and export virtual water. From the specific flow volume, there are differences between the grain virtual balance volume and net inflow volume, ranging from zero to hundreds of billion cubic meters. In general, the virtual water flow from the north to the south, which aggravates the unbalanced allocation of regional resources to a certain extent.

(2) Optimization of grain virtual water trade with opportunity cost

Based on the transportation cost minimization optimization model, we add opportunity cost and establish the total cost (means transportation cost and opportunity cost) minimization optimization model. In this way, we can not only emphasize the endowment conditions of the water resources but also the other factors when applied virtual water strategy. Taking the opportunity cost into account making a better understanding of grain virtual water trade from the perspective of the economic value of water resources. The results show that there are 18 inputs and 13 outputs areas in the grain virtual water trade. The huge virtual flow is generated, up to 1179.24 billion cubic meters of water, which accounted for $4.32 \%$ of the total water resources of the country in 2014 , accounting for $30.47 \%$ of the agricultural water. Furthermore, the virtual water output area is very concentrated, which the concentration of resources is high and a small number of areas occupy an advantageous position.

(3) The advantages of the optimized method of grain virtual water trade

Comparing the results of grain virtual water trade with the minimization of transportation cost and total cost, we can find that the optimization model of minimizing total cost has several advantages. First, it can overcome the unreasonable virtual water trade in the case of minimizing transportation 
cost, that is to say, preventing areas with high water opportunity costs flowing to areas with low opportunity costs. As a result, it enables limited water resources to be allocated to more efficient uses. Second, the trade network of grain virtual water doesn't become more complicated. And the long-tail effect of a trade optimization scheme considering the opportunity cost is more obvious, which means that the result is closer to the actual situation. Third, when considering the opportunity cost of trade, the economic value can not only fill the costs of transportation but will eventually produce additional economic benefits in that virtual water trade.

According to the results, some important implications are presented below.

(1) It is imperative that the government conduct virtual water strategies for realizing sustainable water resources. The implementation of virtual water strategies is not a problem that a region or a province can solve with its own strength. It needs to stand at the height of the whole country and solve the problem at the national level. This can be achieved by introducing new water resource management, combining entity water with virtual water, breaking through natural restrictions of entity water allocation, and comparing internal and external advantages.

(2) Taking the optimization results of grain virtual water trade, considering the opportunity cost as an example, more factors should be considered in studying virtual water strategies. Virtual water trade reflects the production technology level of a country and the opportunity cost of a series of limited resources, which is also the case for a region. Whether or not to adopt virtual water trade depends not only on the water resources of a region but also on the opportunity cost and relative advantage of the product. Therefore, emphasis should be laid on the related natural conditions, social and economic conditions, and ecological environment.

(3) With respect to the directions for future research, there are some interesting extensions, 
including: 1) Conducting a long term study analysis of grain virtual water trade in China to under the variability in time. 2) Exploring the impacts and interactions of grain virtual water trade on the local social, economic, environmental, cultural, natural, and political situation.

\section{Acknowledgments}

This study was supported by the National Key Research and Development Program of China (NO.2017YFC0403504) and the National Science Foundation of China (NO.51479119 and 51579064). The authors thank the editor and the anonymous reviewers for their comments, which helped improve the quality of the paper.

\section{References}

Abu-Sharar, T., Al-Karablieh, E., Haddadin, M., 2012. Role of Virtual Water in Optimizing Water Resources Management in Jordan. Water Resour. Manag. An Int. Journal, Publ. Eur. Water Resour. Assoc. 26, 3977-3993.

Allan, J.A., 1993. Fortunately there are substitutes for water otherwise our hydro-political futures would be impossible. Priorities water Resour. Alloc. Manag. 13.

Allan J.A., 1994. Overall perspectives on countries and regions. In: Rogers, P. and Lydon, P. Water in the Arab World: perspectives and prognoses, Harvard University Press, Cambridge, Massachusetts. 65-100.

Allan, J.A., Olmsted, J.C., 2003. Politics, economics and (virtual) water: A discursive analysis of water policies in the Middle East and North Africa. Res. Middle East Econ. https://doi.org/10.1016/S1094-5334(03)05007-6

Ansink, E., 2010. Refuting two claims about virtual water trade. Ecol. Econ. 69, 2027-2032.

Ben, P., Wu, S., Li, X., Zhou, S., 2016. China's inter-provincial grain trade and its virtual cultivated land flow simulation. Geogr. Res. 8, 5.

Chapagain, A.K., Hoekstra, A.Y., 2003. Virtual water flows between nations in relation to trade in livestock and livestock products.

Chapagain, A.K., Hoekstra, A.Y., 2011. The blue, green and grey water footprint of rice from production and consumption perspectives. Ecol. Econ. 70, 749-758. 
Cheng G., 2006. Virtual water-a new approach to China's water resources security strategy. Bulletin of Chinese Academy of Sciences. 260-265 (in Chinese).

Chen, G.Q., Li, J.S., 2015. Virtual water assessment for Macao, China: highlighting the role of external trade. J. Clean. Prod. 93, 308-317.

Chen, W., Wu, S., Lei, Y., Li, S., 2017. China's water footprint by province, and inter-provincial transfer of virtual water. Ecol. Indic. 74, 321-333. https://doi.org/10.1016/j.ecolind.2016.11.037

Chen, Z.M, Chen, G.Q., 2013. Virtual water accounting for the globalized world economy: National water footprint and international virtual water trade. Ecol. Indic. 28, 142-149. https://doi.org/10.1016/j.ecolind.2012.07.024

China Food Industry Association, 2015. China Food Industry Yearbook 2015. Zhonghua Book Company Publishing House. Beijing.

Dalin, C., Hanasaki, N., Qiu, H., Mauzerall, D.L., Rodriguez-Iturbe, I., 2014. Water resources transfers through Chinese interprovincial and foreign food trade. Proc. Natl. Acad. Sci. 111, 9774-9779.

Dalin, C., Qiu, H., Hanasaki, N., Mauzerall, D.L., Rodriguez-Iturbe, I., 2015. Balancing water resource conservation and food security in China. Proc. Natl. Acad. Sci. 112, 4588-4593. https://doi.org/10.1073/pnas.1504345112

Department of rural social and economic investigation, National Bureau of Statistics, 2015. China Rural Statistical Yearbook 2015. China Statistical Publishing House, Beijing.

Dong M., 2016. Study on the optimization of Xinjiang virtual water trade structure. Shihezi University (in Chinese).

El-Sadek, A., 2010. Virtual water trade as a solution for water scarcity in Egypt. Water Resour. Manag. 24, 2437-2448.

Feng, K., Siu, Y.L., Guan, D., Hubacek, K., 2012. Assessing regional virtual water flows and water footprints in the Yellow River Basin, China: A consumption based approach. Appl. Geogr. 32, 691-701. https://doi.org/10.1016/j.apgeog.2011.08.004

Guan, D., Hubacek, K., 2007. Assessment of regional trade and virtual water flows in China. Ecol. Econ. 61, 159-170.

Hoekstra, A.Y., Hung, P.Q., 2002. A quantification of virtual water flows between nations in relation to international crop trade. Water Res. 49, 203-9.

Hoekstra, A.Y., Hung, P.Q., 2005. Globalisation of water resources: International virtual water flows in relation to crop trade. Glob. Environ. Chang. 15, 45-56. https://doi.org/10.1016/j.gloenvcha.2004.06.004 
Jiang, S., Wang, J., Zhao, Y., Shang, Y., Gao, X., Li, H., Wang, Q., Zhu, Y., 2017. Sustainability of water resources for agriculture considering grain production, trade and consumption in China from 2004 to 2013. J. Clean. Prod. 149, 1210-1218. https://doi.org/10.1016/j.jclepro.2017.02.103

Jiang, Y., Cai, W., Du, P., Pan, W., Wang, C., 2015. Virtual water in interprovincial trade with implications for China's water policy. J. Clean. Prod. 87, 655-665.

Zhang, C., Anadon, L.D., 2014. A multi-regional input-output analysis of domestic virtual water trade and provincial water footprint in China. Ecol. Econ. 100, 159-172.

Li, M., Fu, Q., Singh, V.P., Liu, D., 2018. An interval multi-objective programming model for irrigation water allocation under uncertainty. Agric. Water Manag. 196, 24-36.

Ma, J., Hoekstra, A.Y., Wang, H., Chapagain, A.K., Wang, D., 2006. Virtual versus real water transfers within China. Philos. Trans. R. Soc. B Biol. Sci. 361, 835-842.

Ministry of environment of China, 2015. China's Environmental Yearbook 2015, China Environmental Yearbook press, Beijing.

National Bureau of Statistics, 2015. China Statistical Yearbook 2015. China Statistical Publishing House, Beijing.

Sun C., Zhang L., 2009. Evolution of China's agricultural products' virtual water-cultivated land resources from the perspective of regional spatial-temporal difference. Resour Sci. 31, 84-93.

Wang, Y.B., Wu, P.T., Zhao, X.N., Engel, B.A., 2014. Virtual water flows of grain within China and its impact on water resource and grain security in 2010. Ecol. Eng. 69, 255-264.

Wichelns, D., 2001. The role of "virtual water" in efforts to achieve food security and other national goals, with an example from Egypt. Agric. water Manag. 49, 131-151.

Xu C.X., Mao C., Tian G.L., Xie W.X., 2010. Research on the function mechanism and contribution share of virtual water trade to regional economy. Chinese Soft Science. 110-119 (in Chinese).

Yang L,.2009. Analysis of grain supply and demand balance in China. Shandong University of technology, Zibo city (in Chinese).

Ye, Q., Li, Y., Zhuo, L., Zhang, W., Xiong, W., Wang, C., Wang, P., 2018. Optimal allocation of physical water resources integrated with virtual water trade in water scarce regions: A case study for Beijing, China. Water Res. 129, 264-276.

Zhang, C., Zhong, L., Liang, S., Sanders, K.T., Wang, J., Xu, M., 2017. Virtual scarce water embodied in inter-provincial electricity transmission in China. Appl. Energy 187, 438-448.

Zhang, Z., Yang, H., Shi, M., 2011. Analyses of water footprint of Beijing in an interregional inputoutput framework. Ecol. Econ. 70, 2494-2502.

Zhuo, L., Mekonnen, M.M., Hoekstra, A.Y., 2016. Water footprint and virtual water trade of China: Past and future. 
593 Zou J., Hu J., Yang Y.R., 2010. Study on the dynamic change of virtual water balance in China's grain production and consumption. Chinese Journal of eco agriculture.18: 185-188 (In Chinese).

595 Zou J., Xie Y.H., Li B.H., Tian Y.P., Mao D.H., 2010. Study on the optimization of spatial distribution 596 of grain production in China under the background of virtual water strategy. Regional Research and Development. 29: 22-27 (in Chinese). 